\title{
The engagement of microglia in tau-targeted immunotherapy in Alzheimer's disease
}

\author{
Denisa Palova ${ }^{1,2}$, Natalia Turic Csokova ${ }^{1,2}$, Karina Markova ${ }^{2}$, Eva Kontsekova ${ }^{1,2}$, Branislav \\ Kovacech $^{1,2}$ and Monika Zilkova ${ }^{1,2}$ \\ ${ }^{1}$ Institute of Neuroimmunology, Slovak Academy of Sciences, Bratislava, Slovakia \\ ${ }^{2}$ Axon Neuroscience R\&D Services SE, Bratislava, Slovakia
}

\begin{abstract}
Alzheimer's disease (AD) is an age-related neurodegenerative disease characterized by progressive memory decline, histopathological lesions such as amyloid $\beta$ plaques and neurofibrillary tangles, and neuroinflammation driven by glial cells. Microglia, the innate immune cells of the brain, dynamically survey their environment for signs of infection and cell damage. Although our understanding of microglia and their modes of activation has expanded in recent years, their role in $\mathrm{AD}$ is still not completely understood. Broad range of microglia phenotypes, from neuroinflammatory to neuroprotective, found in neurodegenerative diseases make their role difficult to discern. In this review, we summarize activities of microglia in healthy and $\mathrm{AD}$ brains and their possible role during immunotherapy targeted against pathological tau proteins.
\end{abstract}

Key words: Alzheimer's disease - Microglia - Neuroinflammation - Tau immunotherapy

\begin{abstract}
Abbreviations: $A \beta$, amyloid $\beta$; $A D$, Alzheimer's disease; $A P P, \beta$-amyloid precursor protein; $C N S$, central nervous system; DAM, disease associated microglia; eTau, extracellular tau; Fc $\gamma R$, Fc gamma receptor; GSK $3 \beta$, glycogen synthase kinase $3 \beta$; IFN $\gamma$, interferon gamma; IgG, immunoglobulin G; IL, interleukin; ITAM, immunoreceptor tyrosine activating motifs; ITIM, immunoreceptor tyrosine inhibitory motifs; LPS, lipopolysaccharide; MAPK, mitogen-activated protein kinase; NFT, neurofibrillary tangles; PET, positron emission tomography; PHF, paired helical filaments; PRR, pattern recognition receptors; ROS, reactive oxygen species; SRA, scavenger receptor A; TLR, toll-like receptors; TNFa, tumour necrosis factor alpha; TREM2, triggering receptor expressed in myeloid cells 2; TSPO, mitochondrial translocator protein; UPS, ubiquitin-proteasome system.
\end{abstract}

\section{Introduction}

Alzheimer's disease (AD) is the most prevalent type of dementia with proteinopathy being the key pathogenic trigger. Two main pathological hallmarks of $\mathrm{AD}$ are the accumulation of extracellular amyloid $\beta$ plaques $(A \beta)$ and intracellular

Correspondence to: Denisa Palova, Institute of Neuroimmunology, Slovak Academy of Sciences, Dubravska cesta 5779/9, Bratislava, Slovakia

E-mail: denisa.palova@savba.sk neurofibrillary tangles (NFTs) (Prince et al. 2015). Numerous studies point out the significant contribution of neuroinflammation in AD pathology. Analysis of AD brains revealed the presence of activated microglia and neuroinflammation in the brain tissues affected by neurodegeneration (Sheffield et al. 2000; Gebicke-Haerter 2001; Ishizawa and Dickson 2001; Gerhard et al. 2006; Cosenza-Nashat et al. 2009; Keren-Shaul et al. 2017). Microglia are the innate immune cells of the central nervous system (CNS) that help maintain homeostasis of the brain, promote learning and memory, and respond to various pathogenic stimuli in different

(C) The Authors 2021. This is an open access article under the terms of the Creative Commons Attribution-NonCommercial 4.0 International License (https://creativecommons.org/licenses/by-nc/4.0/), which permits non-commercial use, distribution, and reproduction in any medium, provided the original work is properly cited. 
brain areas throughout the lifespan (Colonna and Butovsky 2017; Lenz and Nelson 2018). The role of microglia in the $\mathrm{AD}$ neuropathology is not fully understood. It is assumed that their activation might be beneficial at the beginning of the disease, but it seems to turn rather detrimental in later stages (Jay et al. 2015, 2017; Jiang et al. 2016; Bemiller et al. 2017; Leyns et al. 2017). Microglia mediate a phagocytic clearance of pathologic protein aggregates from the brain (Luo et al. 2015; Rivera-Escalera et al. 2019), while chronic activation of microglia shifts their phenotype towards more pro-inflammatory, which together with gradual deterioration of phagocytic activity promote neuroinflammation and neurotoxicity (Keren-Shaul et al. 2017).

For decades, the amyloid hypothesis has dominated research on $\mathrm{AD}$. Amyloid hypothesis is based on the principle of serial causality, where the primary pathogenic trigger is the accumulated $A \beta$ that initiates and drives subsequent tau hyperphosphorylation, as well as other clinical and histopathological features of AD (Hardy and Higgins 1992). Since the formulation of amyloid cascade hypothesis over 30 years ago, number of alternative hypotheses emerged. Tau hypothesis postulates that aberrant accumulation of hyperphosphorylated tau aggregates precedes $\mathrm{A} \beta$ pathology (Braak and Braak 1997; Braak and Del Tredici 2011) and that the development and localisation of tau pathology closely correlate with other measures of neurodegenerative disease progression including neuronal dysfunction and death, synaptic loss, and cognitive decline (Arriagada et al. 1992; Giannakopoulos et al. 2003; Small and Duff 2008; Polydoro et al. 2009). In addition, tau pathology progresses along interconnected neuroanatomical pathways in a disease-specific pattern (Braak and Braak 1995; Braak et al. 2011). Both hypotheses are not mutually exclusive, as common upstream drivers, such as GSK3 $\beta$ (glycogen synthase kinase $3 \beta$ ), a key enzyme in tau phosphorylation and APP ( $\beta$-amyloid precursor protein) metabolism, may cause parallel elevation in $A \beta$ and tau hyperphosphorylation through independent mechanisms (Phiel et al. 2003; Liu et al. 2006).

\section{The role of microglia in the central nervous system under normal and pathological conditions}

\section{Healthy brain microglia}

\section{Origin and functions}

As was shown in mice, microglia arise from extra-embryonic yolk sac myeloid progenitors in early embryonic development (embryonic day 7.5), as opposed to other tissue-resident macrophages that are derived from fetal hematopoietic stem cells (Alliot et al. 1999; Ginhoux et al. 2010; Sheng et al. 2015). In humans, the microglial popula- tion density ranges from $0.5 \%$ to $16.6 \%$ of the total cells in the brain (Mittelbronn et al. 2001). Microglial progenitors enter the CNS before blood-brain barrier is formed and their population is primarily maintained through self-renewal of CNS-resident microglia (Ajami et al. 2007). However, small degree of renewal is achieved through infiltrating bone marrow-derived monocytes, especially under pathological conditions (Varvel et al. 2016). This self-sustaining feature of microglia makes them particularly sensitive to local disturbances. Primary function of microglia is to survey their microenvironment, scavenge cell debris and damaged brain cells, eliminate dysfunctional or less active synapses (synaptic pruning), modulate synaptic transmission by paracrine signaling, and to provide trophic support for neurons (Wes et al. 2016). Disrupted synaptic pruning negatively affects learning processes, and eventually may contribute to the synaptic loss observed in AD (Chung et al. 2015). Increasing body of evidence suggests that microglia derived from different CNS compartments display distinct functions and phenotypes (Olah et al. 2018, 2020; Swanson et al. 2020). We have shown that neonatal murine microglia derived from brain cortex exhibit more anti-inflammatory phenotype and promote neurogenesis, while spinal cord-derived microglia are prone to be more pro-inflammatory in nature (Murgoci et al. 2020). As microglia are mitotically-active cells, Reu and colleagues analysed microglial turnover in the human brain. Microglia were shown to renew at a relatively slow pace, with an estimated median rate of $28 \%$ per year and have an average life span of 4.2 years (Reu et al. 2017).

\section{Microglia phenotypes}

Classical dogma of both resident macrophages and microglia is that they display two main phenotypes, "activated" (or M1) phenotype and "resting" (or M2) phenotype. M1 phenotype is also known as a pro-inflammatory state, in which secretion of cytokines interleukin-1 $\beta$ (IL1 $\beta)$, interleukin-6 (IL6), interleukin-12 (IL12), interleukin-18 (IL18), tumour necrosis factor- $\alpha(\mathrm{TNF} \alpha)$ dominates. On the other hand, M2 state is characterized by elevated phagocytic activity without production of toxic nitric oxide (NO) and by the expression of anti-inflammatory cytokines interleukin-4 (IL4), interleukin-10 (IL10), interleukin-13 (IL13) and transforming growth factor- $\beta$ (TGF $\beta$ ) (Goerdt and Orfanos 1999; Mantovani et al. 2002; KoenigsknechtTalboo and Landreth 2005; Zelcer et al. 2007). We now understand, that microglial phenotypes are far more heterogenic and overlapping than originally thought, and that "resting" microglia are in fact motile and constantly surveying their environment, thus helping maintain brain homeostasis (Wes et al. 2016). Dynamic change of microglia polarization depends on multiple factors and accumulating evidence point at the role of mitochondria in this transi- 
tion (Ferger et al. 2010; Pozzo et al. 2019; Ren et al. 2020). Ferger et al. (2010) for example reported that some aspects of alternative M2 microglial activation induced by IL4 depend on functional mitochondria. Because this alternative activation is implicated in dampening of inflammation, mitochondrial dysfunction in microglia might contribute to the detrimental effects of neuroinflammation on neurodegeneration. Additionally, mitochondrial translocator protein (TSPO), located on the outer mitochondrial membrane, has been thought to have a homeostatic function in neuroinflammatory conditions. To counteract the proinflammatory state of microglia, activated TSPO reduces production of reactive oxygen species (ROS) and stimulates neurosteroidogenesis (Pozzo et al. 2019). Upon aging, microglia typically exhibit a change in morphology including thickening, de-ramification and hypertrophy of the cell body. In addition to morphological changes, increased expression of surface markers CD11b, CD68, CD11c and F4/80 was reported in the mouse brains (Hart et al. 2012). Age-related morphological changes in murine microglia are in accordance with those in human microglia. It was shown that microglial processes shorten with age, exhibit less branching and reduced arborized area (Davies et al. 2017). Moreover, Keren-Shaul and colleagues described and characterized a new type of microglia in the brain cortex with the aid of single-cell RNA-sequencing, called disease associated microglia - DAM (Keren-Shaul et al. 2017) (see next chapter for more details).

\section{Antibody effector function}

Microglia express Fc gamma receptors (Fc $\gamma \mathrm{R}$ ) I, IIb, III and IV which are involved in the internalisation of antigen-antibody immune complexes destined for intracellular degradation. The constant region $(\mathrm{Fc})$ of immunoglobulin $\mathrm{G}(\mathrm{IgG})$ antibody protruding from the immune complexes is recognized by surface $\mathrm{F} c \gamma \mathrm{R}$, leading to their internalization by microglia. Fc $\gamma$ R clustering on the cell surface is required for the phosphorylation of cytoplasmic motifs on the receptor. Mice express three classes of activating IgG receptors Fcgr1, Fcgr3 and Fcgr4. Binding of antibodies to activating Fc $\gamma \mathrm{R}$ results in phosphorylation of immunoreceptor tyrosine activating motifs (ITAMs) and down-stream activation pathways activating the cell. Low-affinity inhibitory receptors $\mathrm{F} c \gamma \mathrm{R}$ IIb contain immunoreceptor tyrosine inhibitory motifs (ITIM) in their intracellular domain. Phosphorylation of ITIM results in initiating inhibitory signalling pathways (Fuller et al. 2014). With increasing age, murine microglia exhibit elevated expression of Fcgr1 (Hart et al. 2012). Microglia also express toll-like receptors (TLR), pattern recognition receptors (PRR) and scavenger receptor A (SRA) which mediate phagocytosis of non-antibody bound ligands (Olson and Miller 2004; Zhang et al. 2014).

\section{Microglia in Alzheimer's disease}

Microglia actively help maintain brain homeostasis and functions in the prodromal or early stages of AD. However, under conditions of chronic neuroinflammation, influenced by numerous environmental and/or genetic factors, the pathogenesis of $\mathrm{AD}$ may start to develop. Main cell types involved in neuroinflammatory processes in brain are microglia and astrocytes, but capillary endothelial cells and infiltrating blood cell can also contribute to neuroinflammation, especially when the blood brain barrier functions are compromised (Montagne et al. 2015; Varvel et al. 2016). Activated microglia have been shown to colocalize with deposits of NFTs and A $\beta$ plaques in human brains (Cras et al. 1991; Overmyer et al. 1999; Sheffield et al. 2000; KerenShaul et al. 2017). Although microglia are more activated in later stages of tangle formation, their phagocytic activity is getting compromised (Bolos et al. 2016).

\section{Primed microglia and immune memory}

In an ageing brain, microglia are prone to become hypersensitive to repeated exposure to inflammatory stimuli, a phenomenon known as "priming". This means that primed microglia have a lower threshold for activation and can become harmful upon further stimulation. Microglial priming was first described in the brains of mice with prion disease, as diseased mice showed an elevated microglial inflammatory response after systemic administration of lipopolysaccharide (LPS) or polyinosinic:polycytidylic acid (poly I:C) (Cunningham et al. 2005). Microglial priming is generally considered maladaptive and detrimental. Molecular pathways involved in the mechanism of microglial priming remain only partially elucidated. Up-regulation of $I l 1 \mathrm{~b}, \mathrm{Mhc2}$ gene expression and reduction of $\mathrm{C} \times 3 \mathrm{cr} 1$ Cx3cl1 signalling cascade was previously reported (Field et al. 2010; Holtman et al. 2015b). Priming of microglia may be a consequence of cellular aging and environmental factors inducing e.g. ischaemia, traumatic brain injury (Leng and Edison 2021), or chronic low-grade systemic inflammation, as can be seen in atherosclerosis, type 2 diabetes mellitus, obesity, high fat diet (Casserly and Topol 2004; Balakrishnan et al. 2005; Donath and Shoelson 2011; Drake et al. 2011; Butler et al. 2020). Interestingly, emerging evidence points toward epigenetic regulation of inflammatory pathways implicated in microglial priming. Matt et al. (2016) found that expression of DNA methylating enzymes is decreased in aged murine microglia, and that decreased methylation in the promotor region of $I l 1 b$ gene results in increased intracellular production of IL1. In another study, specific inhibition of histone deacetylases 1 and 2 resulted in reduced LPS-mediated expression of cytokines in BV2 murine microglia (Durham et al. 2017). Several investigators 
propose that microglial priming is a form of innate immune memory, as it exhibits similarities with trained immunity of peripheral macrophages. After the activating stimulus of microglia subdues, a long-lasting epigenetic memory of the stimuli may remain in the form of histone post-translational modification, specifically by $\mathrm{H} 3 \mathrm{~K} 4 \mathrm{mel}$ marks located at defined latent enhancer sites in the microglial genome. Upon re-encounter of the stimuli, these latent enhancers may play role in the augmented inflammatory response (Haley et al. 2019; Neher and Cunningham 2019).

\section{Disease-associated microglia (DAM)}

DAM are recently identified subset of microglia found at sites of neurodegeneration. During the onset of neurodegenerative disease, microglia evolve to DAM through a two-step mechanism, (i) TREM2-independent and (ii) TREM2dependent. This transition is associated with significant changes in gene expression. The first step in DAM activation, TREM2-independent, is associated with down-regulation of several important microglia homeostatic genes, including those for purinergic receptors $P 2 r y 12 / P 2 r y 13, C x 3 c r 1$, Tmem119 and up-regulation of ApoE, TREM2 adaptor Tyrobp, and $B 2 m$ gene expression. The second phase of DAM activation, TREM2-dependent, involves up-regulation of multiple genes such as Cst7, Ctsd, Lpl, and Trem2, which are involved predominately in lysosomal/phagocytic pathways, endocytosis, lipid metabolism. These results support the observation that deficiency in TREM2 in the late stage of $\mathrm{AD}$ in a mouse model exacerbated disease, led to microglial dysfunction and apoptosis (Keren-Shaul et al. 2017). Other research groups similarly reported microglial subpopulation with disease-specific expression profile (Holtman et al. 2015a; Krasemann et al. 2017; Kang et al. 2018). A precise identification of molecular mediators that trigger the DAM phenotype might offer interesting and plausible approach for future neuroprotective therapies.

\section{TREM2}

The TREM2 gene (triggering receptor expressed in myeloid cells 2) encodes a single-pass transmembrane receptor expressed by microglia, that induces phagocytosis, promotes survival and modulates inflammatory signalling pathways (Ulland and Colonna 2018). TREM2 was shown to act as a microglial sensor that recognises anionic and zwitterionic lipids exposed on the cell surface of neurons damaged by $\mathrm{A} \beta$ pathology (Wang et al. 2015). TREM 2 is considered as a high-risk genetic factor for AD. The rs75932628 $(\mathrm{R} 47 \mathrm{H})$ polymorphism of TREM2 was associated with up to three-fold increased risk of nonfamilial AD (Jonsson et al. 2013). Homozygous loss-of-function mutations in TREM2 cause a severe, rare form of dementia with bone cystic le- sions known as Nasu-Hakola disease (Bianchin et al. 2004). Based on their findings, Gratuze and colleagues proposed that the role of TREM 2 depended on $A \beta$ pathology and the stage of the disease (Gratuze et al. 2020). At early phases of the disease, the $\mathrm{R} 47 \mathrm{H}$ variant reduces microgliosis around senile plaques, thereby increasing their number, and also promotes tau propagation. However, in advanced stages of the disease, when tau pathology is prominent, this variant attenuates tau-dependent synapse loss by reducing microglial phagocytosis.

\section{Mitochondrial dysfunction}

Mitochondrial dysfunction is critically involved in AD pathology. AD-associated chronic exposure to pathogenic stimuli directly alters metabolic processes in the brain (Brooks et al. 2007; Kapogiannis and Mattson 2011; Mastroeni et al. 2017; Croteau et al. 2018). Large body of evidence suggests that pathological forms of tau negatively affect mitochondria, including (i) mitochondrial transport (Schulz et al. 2012; Shahpasand et al. 2012), (ii) morphology (DuBoff et al. 2012; Amadoro et al. 2014), and (iii) bioenergetics (David et al. 2005; Rhein et al. 2009; Quintanilla et al. 2014). Studies on transgenic mice with P301L mutant tau revealed, that complex I of mitochondrial respiratory chain is especially sensitive to abnormal tau (David et al. 2005; Rhein et al. 2009), and reversely, mitochondrial stress per se was shown to promote hyperphosphorylation of tau in a mouse model of oxidative stress that lacks superoxide dismutase 2 (SOD2) (Melov et al. 2007). Optimal calcium concentration in mitochondria is inevitable for normal function. Xie et al. (2017) showed that reduction of excessive calcium uptake by mitochondria prevented apoptosis of A $\beta$-treated BV2 microglia-like cells and primary mouse microglia. Some authors suggest that modulating microglial metabolism might be an interesting new approach for treating AD. In this regard, Baik and colleagues observed that acute exposure to $A \beta$ triggers metabolic reprogramming of microglia from oxidative phosphorylation to glycolysis, which is mTORdependent. However, chronic exposure to $A \beta$, represented by a mouse model of AD (5XFAD mice), was associated with metabolic defect, which were restored by IFN $\gamma$ treatment (Baik et al. 2019). Additional studies are needed to elucidate the role of tau pathology in mitochondrial metabolic (dys) functions in microglia.

\section{Senescence}

With increasing age, microglia undergo replicative senescence, and are subjected to changes in telomere length, proliferation rate and morphology (Flanary and Streit 2004; Miller and Streit 2007). Bussian and colleagues investigated the role of senescent glial cells in the onset and progression 
of tauopathy. To test this, authors used animal model of tauopathy, PS19 transgenic mice overexpressing mutant human tau in neurons. These mice accumulated senescent microglia and astrocytes, as indicated by the expression of markers of senescence, such as p16, p19, p21, Pail and Casp8. Clearance of these senescent cells via transgenic approach (INK-ATTAC mice) or pharmacological intervention (senolytic agent ABT263) prevented gliosis, hyperphosphorylation of both soluble and insoluble tau and cortical/hippocampal neurodegeneration (Bussian et al. 2018). This approach might provide a new therapeutic challenge for the treatment of tauopathies.

\section{Neuroinflammation}

\section{Mediators}

Neuroinflammation is defined as an activation of the resident immune cells of brain in reaction to injury, disease or infection, with an aim of rapid localization and elimination of pathogen. Typical mediators of neuroinflammatory responses in brain are pro-inflammatory cytokines (e.g. IL1 $\beta$, IL6, TNFa), chemokines (e.g. CCL2, CCL5, CXCL1), small molecule messengers (e.g. nitric oxide-NO, prostaglandins) and ROS. Most of these inflammatory signals are being propagated via activated microglia, to a lesser extent by astrocytes (Norden et al. 2016). Whether neuroinflammation is a cause, a contributor, or a consequence of tau pathology is subject to extensive debate. Accumulating evidence points towards chronic neuroinflammation as a crucial factor implicated in the pathogenesis of neurodegenerative diseases (Heneka et al. 2015).

\section{Mechanisms of action}

Mechanistically, we and others proved that misfolded truncated tau aggregates are potent inducers of neuroinflammation (Kovac et al. 2011; Morales et al. 2013). We have demonstrated that primary rat microglia increased production of NO and cytokines IL1 $\beta$, IL6 and TNFa upon exposure to misfolded truncated tau through up-regulated gene expression of MAP-kinases (Jnk, Erk1, p38b) and transcription factors Ap1, Nfkb (Kovac et al. 2011). Similarly, Morales and colleagues (Morales et al. 2013) observed that aggregated tau oligomers and fibrils induced morphological changes and generation of pro-inflammatory IL6 and NO in rat microglia. Hippocampal synapse loss and robust microglial activation preceded the formation of NFTs in P301S transgenic mice overexpressing mutant human tau, thereby linking early microgliosis to the progression of tauopathy (Yoshiyama et al. 2007). On the other hand, activated microglia were shown to further exacerbate tau pathology, thus forming a vicious cycle. Production of proinflammatory cytokines, such as IL1, by activated microglia leads to an increase in tau phosphorylation and cytotoxicity in neurons via the p38 MAP kinase pathway (Sheng et al. 2001; Li et al. 2003). Similar results were obtained after cocultivation of hippocampal neurons with activated astrocytes which led to an increase of NO production and consequently hyperphosphorylation of tau (Quintanilla et al. 2004). Another pro-inflammatory cytokine IL6 was found to promote CDK5 activity, one of the major kinases phosphorylating tau, via a MAPK-p38 dependent pathway (Saez et al. 2004).

\section{Evidence from human brain}

Post mortem analyses of brain tissue in humans suffering from various forms of tauopathies, such as $\mathrm{AD}$, frontotemporal dementia and corticobasal degeneration revealed the presence of activated microglia in brain tissues affected by neurodegeneration (Gebicke-Haerter 2001; Ishizawa and Dickson 2001; Gerhard et al. 2006). Several studies used in vivo PET imaging to investigate neuroinflammation in patients with dementia. Most used PET ligands were targeting TSPO, a marker of activated microglia (Cosenza-Nashat et al. 2009). Study by Cagnin et al. (2001), revealed that cortical areas with high TSPO tracer binding demonstrated the highest rate of atrophy and glucose hypometabolism over 12-24 months follow-up period. Statistically significant differences in inflammation between control and dementia patients were reported and associated with severity of dementia, as indicated by cognitive tests scores. Regions such as the frontal, temporal, parietal, cingulate cortices and hippocampus demonstrated highest correlation of inflammation with cognitive deficits (Versijpt et al. 2003; Edison et al. 2008; Yokokura et al. 2011).

These findings prove a connection between neuroinflammation and processes responsible for neurodegeneration and indicate that long-term activation of immune cells of the CNS can play a pathogenic role in $\mathrm{AD}$ and other types of tauopathies.

\section{Tau clearance mechanisms}

Microglia have been shown to be able to internalise tau protein aggregates both in vitro and in vivo (Luo et al. 2015; Bolos et al. 2016). Surprisingly, it was shown that peripheral macrophages can phagocytose and degrade tau oligomers after LPS stimulation more rapidly than either rat primary microglia or immortalized BV2 microglial cell line (Majerova et al. 2014). Once tau is internalised, its fate is to either undergo degradation via (i) ubiquitin-proteasome system (UPS) or (ii) autophagy-lysosomal pathway. 


\section{Ubiquitin-proteasome system}

Under physiological conditions, tau can be degraded by the $20 \mathrm{~S}$ proteasome in an ubiquitin-independent manner (Grune et al. 2010). Exposure to irreversible proteasome inhibitor lactacystin blocked tau degradation in human neuroblastoma cell line SH-SY5Y (David et al. 2002). However, an ubiquitin-dependent pathway of tau degradation has also been described. In general, misfolded proteins must be refolded by molecular chaperones (e.g. HSC70, HSP70, HSP90) or targeted for degradation by the UPS to prevent aggregation and cytotoxicity. Hsc70-interacting protein (CHIP) acts as an ubiquitin protein ligase facilitating ubiquitination and degradation of abnomal, hyperphosphorylated tau. Sahara et al. investigated, whether the lack of CHIP may be involved in NFT formation. In human AD brains, the protein expression of CHIP was up-regulated, but the amount of PHF-tau (paired helical filament-tau) inversely correlated with the CHIP protein level, suggesting that increases in CHIP may protect against NFT formation in the early stages of AD (Sahara et al. 2005). A reduction in proteasome peptidase activities has been reported in the short-interval post mortem brains of AD patients (Keller et al. 2000; Lopez Salon et al. 2000). Incubation of isolated proteasomes with PHFs derived from AD brains resulted in a marked reduction in the proteasomal activity (Keck et al. 2003).

\section{Autophagy-lysosomal pathway}

Autophagy significantly contributes to tau protein degradation. Treatment of rat hippocampal slice cultures with chloroquine, a lysosomal inhibitor, led to an accumulation of intracellular phosphorylated tau (Bendiske and Bahr 2003). One group has demonstrated, that transfected MEF cell line deficient in ATG5 (autophagy protein) and expressing mutant P301L tau, had significantly attenuated response to starvation-induced autophagy of tau inclusions (Wong et al. 2008). Autophagy receptor proteins such as p62 (Ramesh Babu et al. 2008), NDP52 (Jo et al. 2014), NBR1 (D'Agostino et al. 2011), optineurin (Xu et al. 2019) have been implicated to facilitate tau clearance. Methylene blue has also been shown to be a potent inducer of autophagy. In vivo application of methylene blue to JNPL3 mice with tauopathy resulted in reduction of phosphorylated tau and insoluble fraction of tau in hippocampus (Congdon et al. 2012). Microglia are not the only brain cells capable of phagocytosis, astrocytes also exert a low degree of phagocytic activity. In a study by Martini-Stoica et al. (2018), enhanced expression and activity of transcription factor EB (TFEB) was found in both human brains affected with dementia and transgenic PS19 tauopathy mice. TFEB is a master regulator of lysosomal biogenesis and autophagy. In response to tau pathology, astroglial overexpression of TFEB in mice resulted in reduced tau spreading in vivo.

\section{The role of microglia in tau immunotherapy}

Immunotherapy comprises two approaches, active or passive. In active immunotherapy, a pathogenic antigen is being administered which stimulates the adaptive immune system to elicit a long-lasting immune response. Activated B-lymphocytes undergo the maturation process and produce antibodies with high affinity to the injected antigen. The long-lasting immune response is ensured by generating memory B- and T-cells. In passive immunization, a specific antibody targeted at a pathogen is being directly administered, without inducing any adaptive immune responses. Passive immunization offers a transient form of acquired immunity which can bypass the concerns arising from active immunization, if patients cannot develop their own antibodies. It reduces the risk of permanent immunological adverse effects given by short half-life of the administered antibodies, but also offers the possibility of quantitative modulation of the therapy and for highly specific targeting epitope (Congdon and Sigurdsson 2018).

To date, $A \beta$ immunotherapies for the treatment of $\mathrm{AD}$ have been largely unsuccessful, indicating that treatment may need to be administered earlier in the course of neurodegenerative disease, even before cognitive symptoms start to appear. Recent approval of Biogen's anti-amyloid antibody Aduhelm (formerly known as aducanumab) by FDA (The United States Food and Drug Administration), although heavily criticised within scientific community for the lack of significant evidence, will inevitably revive the interest in immunotherapy against misfolded proteins in $\mathrm{AD}$ (https:// www.alzforum.org/news/series/fallout-continues-afteraducanumab-approval).

Although it is believed that patients at earlier stages of AD might still benefit from this approach, tau immunotherapies might offer a better solution since tau pathology is tightly associated with clinical symptoms and disease progression (Congdon and Sigurdsson 2018). Majority of antibodies that are currently being developed in clinical research as anti-tau immunotherapeutics have an IgG4 isotype, which results in limited effector function due to weak binding of IgG4 to $\mathrm{Fc} \gamma \mathrm{Rs}$ (for details see Table 1). This approach eliminates potential unfavourable effect of microglia activation but at the same time desirable tau clearing properties. In summary, tau-targeting vaccines recognize different tau species and have been suggested to act through various mechanisms: by preventing tau aggregation and cell-to-cell spreading (Theunis et al. 2013; Albayram et al. 2017; Courade et al. 2018; Novak et al. 2018; Albert et al. 2019; Weisova et al. 2019), by facilitating tau uptake by microglia (Zilkova et al. 
2020) and endo-lysosomal degradation of tau in microglia (Andersson et al. 2019) or proteasomal degradation of tau seeds in neurons (McEwan et al. 2017).

\section{Antibody-mediated tau clearance might alleviate tau pathology}

Compelling body of evidence suggest that microglia engulf and degrade tau aggregates more efficiently in a complex with anti-tau antibody, which is an important underlying mechanism of action for the tau-targeted immunotherapy research. Various in vitro studies demonstrated how anti-tau antibodies significantly potentiate uptake and degradation of pathological tau via an Fc-dependent manner in BV2 microglia-like cells (Funk et al. 2015), primary mouse microglia (Luo et al. 2015; Andersson et al. 2019) or primary human microglia (Zilkova et al. 2020). Fc effector function is essential for the antibody-enhanced internalization and degradation of tau by microglia (Fig. 1). Tau-targeted immunotherapies with effector function may effectively suppress tau pathology by inducing tau clearance mechanisms. Selected vaccines, AADvac1 and Lu AF87908, which are being tested in human clinical trials for treatment of $\mathrm{AD}$, have been reported to have this effector function in preclinical research. On the other hand, the rationale for vaccines RO 7105705 and ABBV-8E12 with reduced effector function is

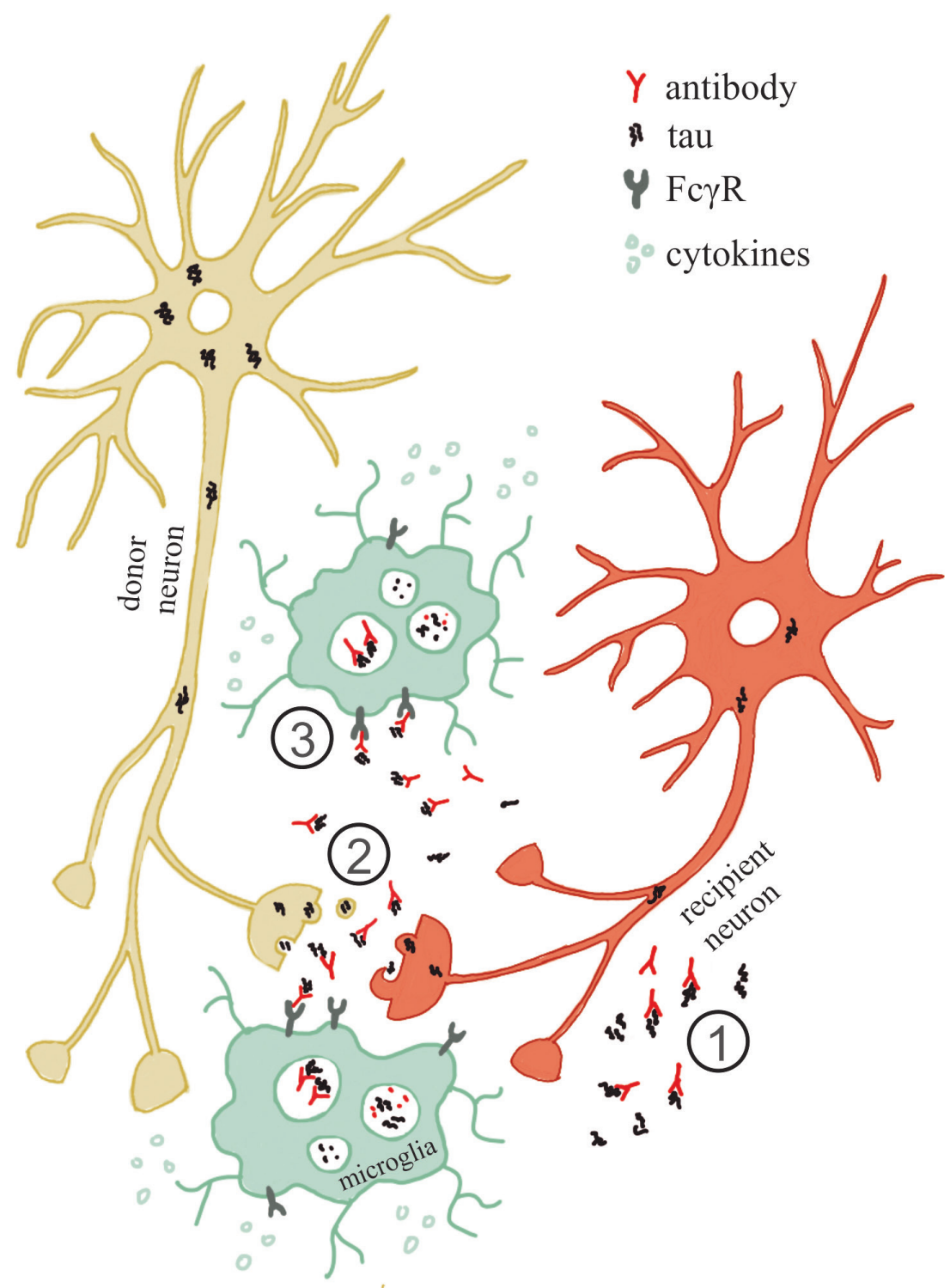

Figure 1. Mechanism of action of anti-tau therapeutic antibody: (1) tau-tau interaction inhibition, (2) tau spreading inhibition, (3) promotion of tau phagocytosis by microglia. 


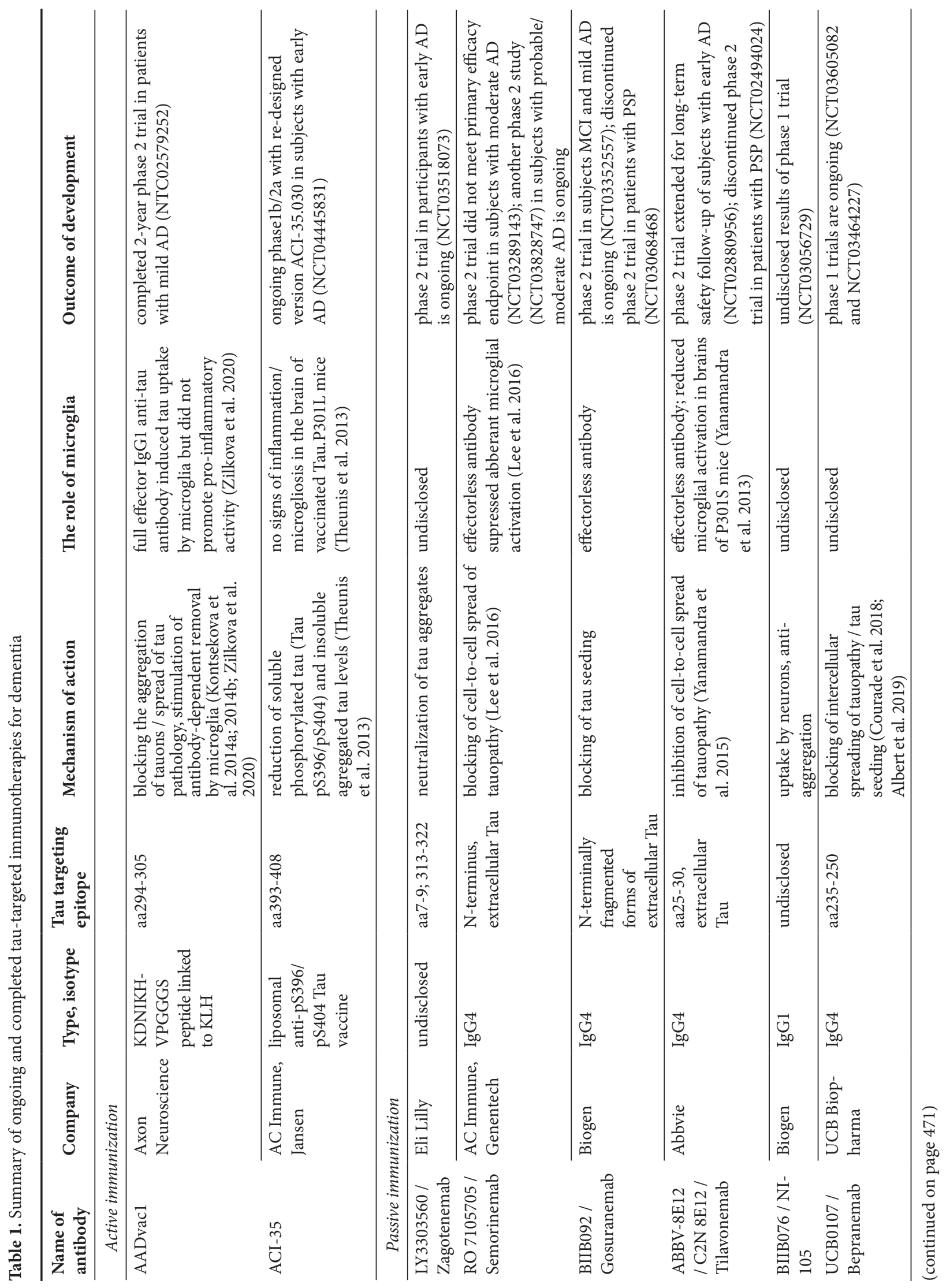


to avoid potentially harmful microglial activation (Novak et al. 2018). Further details of ongoing clinical trials of tautargeting immunotherapies are described in Table 1.

\section{AADvac1}

AADvac1 is one of the only two active anti-tau vaccines that have been in clinical development to date. The aim of AADvac1 active immunization is to induce antibodies that block the spread of tau pathology by immobilizing "tauons" and opsonizing them for removal by the immune system, specifically by microglia (Kontsekova et al. 2014a, 2014b; Novak et al. 2017). Selection of mouse monoclonal antibody DC8E8 preceded AADVac1 vaccine development. Preclinical research has demonstrated that DC8E8 antibody is not internalized by neurons, but it effectively blocked neuronal uptake of pathological tau seeds, which is an important mechanism to prevent spreading of tau pathology (Weisova et al. 2019). DC8E8 and its humanized version AX004, promoted phagocytosis of oligomerized truncated $\operatorname{tau}_{151-391 / 4 \mathrm{R}}$ by human primary microglia isolated from post-mortem brains with dementia via Fc $\gamma$-dependent mechanisms, whereas antibody-tau complexes did not exacerbate pro-inflammatory activity of post-mortem isolated human microglia from AD and non-AD brains (Zilkova et al. 2020). Moreover, successfully completed phase 1 and 2 of AADvac1 clinical trials confirmed safety and effectivity of tau immunotherapy with AADvac1 vaccine in subjects with early/mild AD (see Table 1 for further details) and showed promising results by improving the biomarkers of neurodegeneration and tau pathology (Novak et al. 2021).

\section{Lu AF87908}

Andersson and colleagues demonstrated that $\mathrm{F} c \gamma \mathrm{R}$ binding is necessary for IgG1 antibody-mediated internalization of pathological insoluble tau by primary mouse microglia (Andersson et al. 2019). Consequent clearance of tau was prevented by pharmacological inhibition of lysosomal acidification (chloroquine/ bafilomycin A1). Inhibition of ubiquitin-proteasomal degradation seemed not to abolish the clearance of antibody-bound tau in microglia. This pS396-tau binding antibody reduced seeding of human tau derived from $\mathrm{AD}$ brain in vitro in mouse cortical neurons and in vivo in transgenic rTg4510 mouse model (Rosenqvist et al. 2018), indicating that it neutralizes seed-prone pathological tau. Humanized version of pS396-tau antibody, Lu AF 87908, is being currently investigated in phase 1 clinical trial for safety and tolerability profile (Table 1).

\section{RO 7105705}

RO 7105705 is a passive vaccine containing anti-tau IgG4 humanized antibody that targets extracellular tau (eTau) on 
the $\mathrm{N}$-terminus on all six human tau isoforms, regardless of its monomeric/oligomeric or phosphorylation status. In preclinical research, effectorless antibody directed against the phospho-tau epitope effectively prevented accumulation of tau in neuronal culture without inducing microglial activation and pro-inflammatory cytokine release (Lee et al. 2016). RO 7105705 vaccine is currently in the phase $2 \mathrm{~b}$ trial testing in moderate $\mathrm{AD}$, first phase 2 study did not meet primary endpoint in subjects with prodromal to mild AD (Table 1).

\section{Tilavonemab/C2N 8E12/ABBV-8E12}

$8 \mathrm{E} 12$ is a humanized IgG4 antibody with an aim to target aggregated, pathological eTau's epitope aa25-30 on N-terminus. This antibody acts in extracellular space and blocks pathological tau cell-to-cell spreading in vitro (Kfoury et al. 2012). Furthermore, preclinical research in transgenic P301S mice expressing human mutant tau demonstrated that $8 \mathrm{E} 12$ reduces microglial activation, neurofibrillary pathology, brain atrophy and deficits in the conditioned fear response (Yanamandra et al. 2013; Yanamandra et al. 2015). Effects of 8E12 immunotherapy are currently being investigated in phase 2 clinical trial in people with early AD (Table 1 ).

\section{Summary and conclusion}

Based on the observations from ongoing tau immunotherapies, all anti-tau therapeutic antibodies are aimed to bind abnormal tau proteins, eliminate their toxic functions, prevent their neuronal internalization and/or block intercellular spreading of pathogenic aggregated tau. These antibody properties are independent of the effector function of the antibody. Assuming that an effective therapeutic antibody should eliminate pathological tau proteins from the diseased brain, the effector function of such antibody becomes desirable. Our preclinical data with therapeutic anti-tau antibody AX004 indicate that IgG1 antibodies (with effector function) are more effective in facilitating the uptake of extracellular abnormal tau by adult human microglia than the IgG4 isotype (Zilkova et al. 2020). Moreover, no safety signals have been observed throughout the course of the AADvac1 phase 1 and phase 2 clinical trials, although AADvac1 vaccination generated predominantly IgG1 antibody response in AD patients (Novak et al. 2018). Our data suggest that IgG1 isotype is better suited for therapeutic development.

Microglia are considered the key players in the pathogenesis of $\mathrm{AD}$ and other tauopathies and their activation might be both beneficial and detrimental for the surrounding cells. Microglia displayed only modest phagocytic capacity for pathologic extracellular tau oligomers and this can be further affected by aging and tau pathology progression. Current re- sults from tau immunotherapy show that phagocytic potential of microglia can be accelerated by assistance of therapeutic anti-tau antibodies and indicate the important contribution of microglia to the clearance of tau pathology from $\mathrm{AD}$ brains.

\section{Future directions}

These findings highlight an important role for microglia in $\mathrm{AD}$ progression in both positive and negative ways. It appears that with adequate response to AD immunotherapy, microglia could serve as beneficial effectors of therapeutic antibodies, since they are the primary cell type in the brain to mediate Fc receptor-facilitated antibody effector function. If the potential beneficial effects of microglia in AD immunotherapy are meant to outweigh the risk of overly-activated harmful microglia, further work needs to address: (1) how to reprogram diseased microglia to promote their homeostatic functions, (2) how to enhance microglial clearance of tau and $\mathrm{A} \beta$ aggregates, (3) the complex microglial interaction with neighboring cells in diseased areas of the brain, and (4) the better understanding and functional characterization of diverse populations of microglia in the brain. Further research is also needed to elucidate the mechanistic pathways involved in metabolic de-regulation in microglia, and how modulation of these immuno-metabolic impairments in microglia may ultimately benefit the patients.

Acknowledgement. This work was supported by research grant from the Slovak Research and Development Agency APVV-170642 and APVV-20-0585.

\section{References}

Ajami B, Bennett JL, Krieger C, Tetzlaff W, Rossi FM (2007): Local self-renewal can sustain CNS microglia maintenance and function throughout adult life. Nat. Neurosci. 10, 1538-1543 https://doi.org/10.1038/nn2014

Albayram O, Kondo A, Mannix R, Smith C, Tsai CY, Li C, Herbert MK, Qiu J, Monuteaux M, Driver J, et al. (2017): Cis P-tau is induced in clinical and preclinical brain injury and contributes to post-injury sequelae. Nat. Commun. 8, 1000 https://doi.org/10.1038/s41467-017-01068-4

Albert M, Mairet-Coello G, Danis C, Lieger S, Caillierez R, Carrier S, Skrobala E, Landrieu I, Michel A, Schmitt M, et al. (2019): Prevention of tau seeding and propagation by immunotherapy with a central tau epitope antibody. Brain 142, 1736-1750 https://doi.org/10.1093/brain/awz100

Alliot F, Godin I, Pessac B (1999): Microglia derive from progenitors, originating from the yolk sac, and which proliferate in the brain. Brain Res. Dev. Brain Res. 117, 145-152 https://doi.org/10.1016/S0165-3806(99)00113-3

Amadoro G, Corsetti V, Florenzano F, Atlante A, Ciotti MT, Mongiardi MP, Bussani R, Nicolin V, Nori SL, Campanella M, Calissano P (2014): AD-linked, toxic NH2 human tau affects 
the quality control of mitochondria in neurons. Neurobiol. Dis. 62, 489-507

https://doi.org/10.1016/j.nbd.2013.10.018

Andersson CR, Falsig J, Stavenhagen JB, Christensen S, Kartberg F, Rosenqvist N, Finsen B, Pedersen JT (2019): Antibodymediated clearance of tau in primary mouse microglial cultures requires Fcgamma-receptor binding and functional lysosomes. Sci. Rep. 9, 4658 https://doi.org/10.1038/s41598-019-41105-4

Arriagada PV, Growdon JH, Hedley-Whyte ET, Hyman BT (1992): Neurofibrillary tangles but not senile plaques parallel duration and severity of Alzheimer's disease. Neurology 42, 631-639 https://doi.org/10.1212/WNL.42.3.631

Baik SH, Kang S, Lee W, Choi H, Chung S, Kim JI, Mook-Jung I (2019): A breakdown in metabolic reprogramming causes microglia dysfunction in Alzheimer's disease. Cell Metab. 30, 493-507 https://doi.org/10.1016/j.cmet.2019.06.005

Balakrishnan K, Verdile G, Mehta PD, Beilby J, Nolan D, Galvao DA, Newton R, Gandy SE, Martins RN (2005): Plasma Abeta42 correlates positively with increased body fat in healthy individuals. J. Alzheimers Dis. 8, 269-282 https://doi.org/10.3233/JAD-2005-8305

Bemiller SM, McCray TJ, Allan K, Formica SV, Xu G, Wilson G, Kokiko-Cochran ON, Crish S. D, Lasagna-Reeves CA, Ransohoff RM, et al. (2017): TREM2 deficiency exacerbates tau pathology through dysregulated kinase signaling in a mouse model of tauopathy. Mol. Neurodegener. 12, 74 https://doi.org/10.1186/s13024-017-0216-6

Bendiske J, Bahr BA (2003): Lysosomal activation is a compensatory response against protein accumulation and associated synaptopathogenesis--an approach for slowing Alzheimer disease? J. Neuropathol. Exp. Neurol. 62, 451-463 https://doi.org/10.1093/jnen/62.5.451

Bianchin MM, Capella HM, Chaves DL, Steindel M, Grisard EC, Ganev GG, da Silva Junior JP, Neto Evaldo S, Poffo MA, Walz R, et al. (2004): Nasu-Hakola disease (polycystic lipomembranous osteodysplasia with sclerosing leukoencephalopathy--PLOSL): a dementia associated with bone cystic lesions. From clinical to genetic and molecular aspects. Cell. Mol. Neurobiol. 24, 1-24 https://doi.org/10.1023/B:CEMN.0000012721.08168.ee

Bolos M, Llorens-Martin M, Jurado-Arjona J, Hernandez F, Rabano A, Avila J (2016): Direct evidence of internalization of tau by microglia in vitro and in vivo. J. Alzheimers Dis. 50, 77-87 https://doi.org/10.3233/JAD-150704

Braak H, Braak E (1995): Staging of Alzheimer's disease-related neurofibrillary changes. Neurobiol. Aging 16, 271-278 https://doi.org/10.1016/0197-4580(95)00021-6

Braak H, Braak E (1997): Frequency of stages of Alzheimer-related lesions in different age categories. Neurobiol. Aging 18, 351-357 https://doi.org/10.1016/S0197-4580(97)00056-0

Braak H, Del Tredici K (2011): The pathological process underlying Alzheimer's disease in individuals under thirty. Acta Neuropathol. 121, 171-181 https://doi.org/10.1007/s00401-010-0789-4

Braak H, Thal DR, Ghebremedhin E, Del Tredici K (2011): Stages of the pathologic process in Alzheimer disease: age categories from 1 to 100 years. J. Neuropathol. Exp. Neurol. 70, 960-969
https://doi.org/10.1097/NEN.0b013e318232a379

Brooks WM, Lynch PJ, Ingle CC, Hatton A, Emson PC, Faull RL, Starkey MP (2007): Gene expression profiles of metabolic enzyme transcripts in Alzheimer's disease. Brain Res. 1127, $127-135$ https://doi.org/10.1016/j.brainres.2006.09.106

Bussian TJ, Aziz A, Meyer CF, Swenson BL, van Deursen JM, Baker DJ (2018): Clearance of senescent glial cells prevents tau-dependent pathology and cognitive decline. Nature 562, 578-582 https://doi.org/10.1038/s41586-018-0543-y

Butler MJ, Cole RM, Deems NP, Belury MA, Barrientos RM (2020): Fatty food, fatty acids, and microglial priming in the adult and aged hippocampus and amygdala. Brain Behav. Immun. 89, $145-158$ https://doi.org/10.1016/j.bbi.2020.06.010

Cagnin A, Brooks DJ, Kennedy AM, Gunn RN, Myers R, Turkheimer FE, Jones T, Banati RB (2001): In-vivo measurement of activated microglia in dementia. Lancet 358, 461-467 https://doi.org/10.1016/S0140-6736(01)05625-2

Casserly I, Topol E (2004): Convergence of atherosclerosis and Alzheimer's disease: inflammation, cholesterol, and misfolded proteins. Lancet 363, 1139-1146 https://doi.org/10.1016/S0140-6736(04)15900-X

Chung WS, Welsh CA, Barres BA, Stevens B (2015): Do glia drive synaptic and cognitive impairment in disease? Nat. Neurosci. 18, $1539-1545$ https://doi.org/10.1038/nn.4142

Colonna M, Butovsky O (2017): Microglia function in the central nervous system during health and neurodegeneration. Annu. Rev. Immunol. 35, 441-468 https://doi.org/10.1146/annurev-immunol-051116-052358

Congdon EE, Sigurdsson EM (2018): Tau-targeting therapies for Alzheimer disease. Nat. Rev. Neurol. 14, 399-415 https://doi.org/10.1038/s41582-018-0013-Z

Congdon EE, Wu JW, Myeku N, Figueroa YH, Herman M, Marinec PS, Gestwicki JE, Dickey CA, Yu WH, Duff KE (2012): Methylthioninium chloride (methylene blue) induces autophagy and attenuates tauopathy in vitro and in vivo. Autophagy 8, 609-622 https://doi.org/10.4161/auto.19048

Cosenza-Nashat M, Zhao ML, Suh HS, Morgan J, Natividad R, Morgello S, Lee SC (2009): Expression of the translocator protein of $18 \mathrm{kDa}$ by microglia, macrophages and astrocytes based on immunohistochemical localization in abnormal human brain. Neuropathol. Appl. Neurobiol. 35, 306-328 https://doi.org/10.1111/j.1365-2990.2008.01006.x

Courade JP, Angers R, Mairet-Coello G, Pacico N, Tyson K, Lightwood D, Munro R, McMillan D, Griffin R, Baker T, et al. (2018): Epitope determines efficacy of therapeutic anti-Tau antibodies in a functional assay with human Alzheimer Tau. Acta Neuropathol. 136, 729-745 https://doi.org/10.1007/s00401-018-1911-2

Cras P, Kawai M, Siedlak S, Perry G (1991): Microglia are associated with the extracellular neurofibrillary tangles of Alzheimer disease. Brain Res. 558, 312-314 https://doi.org/10.1016/0006-8993(91)90783-R

Croteau E, Castellano CA, Fortier M, Bocti C, Fulop T, Paquet N, Cunnane SC (2018): A cross-sectional comparison of brain glucose and ketone metabolism in cognitively healthy older 
adults, mild cognitive impairment and early Alzheimer's disease. Exp. Gerontol. 107, 18-26 https://doi.org/10.1016/j.exger.2017.07.004

Cunningham C, Wilcockson DC, Campion S, Lunnon K, Perry VH (2005): Central and systemic endotoxin challenges exacerbate the local inflammatory response and increase neuronal death during chronic neurodegeneration. J. Neurosci. 25, 9275-9284 https://doi.org/10.1523/JNEUROSCI.2614-05.2005

D'Agostino C, Nogalska A, Cacciottolo M, Engel WK, Askanas V (2011): Abnormalities of NBR1, a novel autophagy-associated protein, in muscle fibers of sporadic inclusion-body myositis. Acta Neuropathol. 122, 627-636 https://doi.org/10.1007/s00401-011-0874-3

David DC, Hauptmann S, Scherping I, Schuessel K, Keil U, Rizzu P, Ravid R, Drose S, Brandt U, Muller WE, et al. (2005): Proteomic and functional analyses reveal a mitochondrial dysfunction in P301L tau transgenic mice. J. Biol. Chem. 280, 23802-23814

https://doi.org/10.1074/jbc.M500356200

David DC, Layfield R, Serpell L, Narain Y, Goedert M, Spillantini MG (2002): Proteasomal degradation of tau protein. J. Neurochem. 83, 176-185 https://doi.org/10.1046/j.1471-4159.2002.01137.x

Davies DS, Ma J, Jegathees T, Goldsbury C (2017): Microglia show altered morphology and reduced arborization in human brain during aging and Alzheimer's disease. Brain Pathol. 27, 795-808 https://doi.org/10.1111/bpa.12456

Donath MY, Shoelson SE (2011): Type 2 diabetes as an inflammatory disease. Nat. Rev. Immunol. 11, 98-107 https://doi.org/10.1038/nri2925

Drake C, Boutin H, Jones MS, Denes A, McColl BW, Selvarajah JR, Hulme S, Georgiou RF, Hinz R, Gerhard A, et al. (2011): Brain inflammation is induced by co-morbidities and risk factors for stroke. Brain Behav. Immun. 25, 1113-1122 https://doi.org/10.1016/j.bbi.2011.02.008

DuBoff B, Gotz J, Feany MB (2012): Tau promotes neurodegeneration via DRP1 mislocalization in vivo. Neuron 75, 618-632 https://doi.org/10.1016/j.neuron.2012.06.026

Durham BS, Grigg R, Wood IC (2017): Inhibition of histone deacetylase 1 or 2 reduces induced cytokine expression in microglia through a protein synthesis independent mechanism. J. Neurochem. 143, 214-224 https://doi.org/10.1111/jnc.14144

Edison P, Archer HA, Gerhard A, Hinz R, Pavese N, Turkheimer FE, Hammers A, Tai YF, Fox N, Kennedy A, et al. (2008): Microglia, amyloid, and cognition in Alzheimer's disease: An [11C](R)PK11195-PET and [11C]PIB-PET study. Neurobiol. Dis. 32, 412-419 https://doi.org/10.1016/j.nbd.2008.08.001

Ferger AI, Campanelli L, Reimer V, Muth KN, Merdian I, Ludolph AC, Witting A (2010): Effects of mitochondrial dysfunction on the immunological properties of microglia. J. Neuroinflammation 7, 45 https://doi.org/10.1186/1742-2094-7-45

Field R, Campion S, Warren C, Murray C, Cunningham C (2010): Systemic challenge with the TLR3 agonist poly I:C induces amplified IFNalpha/beta and IL-1beta responses in the diseased brain and exacerbates chronic neurodegeneration. Brain Behav. Immun. 24, 996-1007 https://doi.org/10.1016/j.bbi.2010.04.004

Flanary BE, Streit WJ (2004): Progressive telomere shortening occurs in cultured rat microglia, but not astrocytes. Glia 45, 75-88 https://doi.org/10.1002/glia.10301

Fuller JP, Stavenhagen JB, Teeling JL (2014): New roles for Fc receptors in neurodegeneration-the impact on immunotherapy for Alzheimer's disease. Front. Neurosci. 8, 235 https://doi.org/10.3389/fnins.2014.00235

Funk KE, Mirbaha H, Jiang H, Holtzman DM, Diamond MI (2015): Distinct therapeutic mechanisms of Tau antibodies: Promoting microglial clearance versus blocking neuronal uptake. J. Biol. Chem. 290, 21652-21662 https://doi.org/10.1074/jbc.M115.657924

Gebicke-Haerter PJ (2001): Microglia in neurodegeneration: molecular aspects. Microsc. Res. Tech. 54, 47-58 https://doi.org/10.1002/jemt.1120

Gerhard A, Pavese N, Hotton G, Turkheimer F, Es M, Hammers A, Eggert K, Oertel W, Banati RB, Brooks DJ (2006): In vivo imaging of microglial activation with [11C](R)-PK11195 PET in idiopathic Parkinson's disease. Neurobiol. Dis. 21, 404-412 https://doi.org/10.1016/j.nbd.2005.08.002

Giannakopoulos P, Herrmann FR, Bussiere T, Bouras C, Kovari E, Perl DP, Morrison JH, Gold G, Hof PR (2003): Tangle and neuron numbers, but not amyloid load, predict cognitive status in Alzheimer's disease. Neurology 60, 1495-1500

https://doi.org/10.1212/01.WNL.0000063311.58879.01

Ginhoux F, Greter M, Leboeuf M, Nandi S, See P, Gokhan S, Mehler MF, Conway SJ, Ng LG, Stanley ER, et al. (2010): Fate mapping analysis reveals that adult microglia derive from primitive macrophages. Science 330, 841-845 https://doi.org/10.1126/science.1194637

Goerdt S, Orfanos CE (1999): Other functions, other genes: alternative activation of antigen-presenting cells. Immunity 10, $137-142$ https://doi.org/10.1016/S1074-7613(00)80014-X

Gratuze M, Leyns CE, Sauerbeck AD, St-Pierre MK, Xiong M, Kim N, Serrano JR, Tremblay ME, Kummer TT, Colonna M, et al. (2020): Impact of TREM2R47H variant on tau pathologyinduced gliosis and neurodegeneration. J. Clin. Invest. 130, 4954-4968 https://doi.org/10.1172/JCI138179

Grune T, Botzen D, Engels M, Voss P, Kaiser B, Jung T, Grimm S, Ermak G, Davies KJ (2010): Tau protein degradation is catalyzed by the ATP/ubiquitin-independent 20 S proteasome under normal cell conditions. Arch. Biochem. Biophys. 500, 181-188 https://doi.org/10.1016/j.abb.2010.05.008

Haley MJ, Brough D, Quintin J, Allan SM (2019): Microglial priming as trained immunity in the brain. Neuroscience 405, 47-54 https://doi.org/10.1016/j.neuroscience.2017.12.039

Hardy JA, Higgins GA (1992): Alzheimer's disease: the amyloid cascade hypothesis. Science 256, 184-185 https://doi.org/10.1126/science.1566067

Hart AD, Wyttenbach A, Perry VH, Teeling JL (2012): Age related changes in microglial phenotype vary between CNS regions: 
grey versus white matter differences. Brain Behav. Immun. 26, 754-765 https://doi.org/10.1016/j.bbi.2011.11.006

Heneka MT, Carson MJ, El Khoury J, Landreth GE, Brosseron F, Feinstein DL, Jacobs AH, Wyss-Coray T, Vitorica J, Ransohoff RM, et al. (2015): Neuroinflammation in Alzheimer's disease. Lancet Neurol. 14, 388-405 https://doi.org/10.1016/S1474-4422(15)70016-5

Holtman IR, Noback M, Bijlsma M, Duong KN, van der Geest MA, Ketelaars PT, Brouwer N, Vainchtein ID, Eggen BJ, Boddeke HW (2015a): Glia Open Access Database (GOAD): A comprehensive gene expression encyclopedia of glia cells in health and disease. Glia 63, 1495-1506 https://doi.org/10.1002/glia.22810

Holtman IR, Raj DD, Miller JA, Schaafsma W, Yin Z, Brouwer N, Wes PD, Moller T, Orre M, Kamphuis W, et al. (2015b): Induction of a common microglia gene expression signature by aging and neurodegenerative conditions: a co-expression meta-analysis. Acta Neuropathol. Commun. 3, 31 https://doi.org/10.1186/s40478-015-0203-5

Ishizawa K, Dickson DW (2001): Microglial activation parallels system degeneration in progressive supranuclear palsy and corticobasal degeneration. J. Neuropathol. Exp. Neurol. 60, 647-657 https://doi.org/10.1093/jnen/60.6.647

Jay TR, Miller CM, Cheng PJ, Graham LC, Bemiller S, Broihier ML, Xu G, Margevicius D, Karlo JC, Sousa GL, et al. (2015): TREM2 deficiency eliminates TREM2+ inflammatory macrophages and ameliorates pathology in Alzheimer's disease mouse models. J. Exp. Med. 212, 287-295 https://doi.org/10.1084/jem.20142322

Jay TR, Hirsch AM, Broihier ML, Miller CM, Neilson LE, Ransohoff RM, Lamb BT, Landreth GE (2017): Disease progressiondependent effects of TREM2 deficiency in a mouse model of Alzheimer's disease. J. Neurosci. 37, 637-647 https://doi.org/10.1523/JNEUROSCI.2110-16.2016

Jiang T, Zhang YD, Chen Q, Gao Q, Zhu XC, Zhou JS, Shi JQ, Lu H, Tan L, Yu JT (2016): TREM2 modifies microglial phenotype and provides neuroprotection in P301S tau transgenic mice. Neuropharmacology 105, 196-206 https://doi.org/10.1016/j.neuropharm.2016.01.028

Jo C, Gundemir S, Pritchard S, Jin YN, Rahman I, Johnson GV (2014): Nrf2 reduces levels of phosphorylated tau protein by inducing autophagy adaptor protein NDP52. Nat. Commun. 5,3496 https://doi.org/10.1038/ncomms4496

Jonsson T, Stefansson H, Steinberg S, Jonsdottir I, Jonsson PV, Snaedal J, Bjornsson S, Huttenlocher J, Levey AI, Lah JJ, et al. (2013): Variant of TREM2 associated with the risk of Alzheimer's disease. N. Engl. J. Med. 368, 107-116 https://doi.org/10.1056/NEJMoa1211103

Kang SS, Ebbert MTW, Baker KE, Cook C, Wang X, Sens JP, Kocher JP, Petrucelli L, Fryer JD (2018): Microglial translational profiling reveals a convergent APOE pathway from aging, amyloid, and tau. J. Exp. Med. 215, 2235-2245 https://doi.org/10.1084/jem.20180653

Kapogiannis D, Mattson MP (2011): Disrupted energy metabolism and neuronal circuit dysfunction in cognitive impairment and Alzheimer's disease. Lancet Neurol. 10, 187-198
https://doi.org/10.1016/S1474-4422(10)70277-5

Keck S, Nitsch R, Grune T, Ullrich O (2003): Proteasome inhibition by paired helical filament-tau in brains of patients with Alzheimer's disease. J. Neurochem. 85, 115-122 https://doi.org/10.1046/j.1471-4159.2003.01642.x

Keller JN, Hanni KB, Markesbery WR (2000): Impaired proteasome function in Alzheimer's disease. J. Neurochem. 75, 436-439 https://doi.org/10.1046/j.1471-4159.2000.0750436.x

Keren-Shaul H, Spinrad A, Weiner A, Matcovitch-Natan O, DvirSzternfeld R, Ulland TK, David E, Baruch K, Lara-Astaiso D, Toth B, et al. (2017): A unique microglia type associated with restricting development of Alzheimer's disease. Cell 169, 1276-1290 https://doi.org/10.1016/j.cell.2017.05.018

Kfoury N, Holmes BB, Jiang H, Holtzman DM, Diamond MI (2012): Trans-cellular propagation of Tau aggregation by fibrillar species. J. Biol. Chem. 287, 19440-19451 https://doi.org/10.1074/jbc.M112.346072

Koenigsknecht-Talboo J, Landreth GE (2005): Microglial phagocytosis induced by fibrillar beta-amyloid and IgGs are differentially regulated by proinflammatory cytokines. J. Neurosci. 25, 8240-8249 https://doi.org/10.1523/JNEUROSCI.1808-05.2005

Kontsekova E, Zilka N, Kovacech B, Novak P, Novak M (2014a): First-in-man tau vaccine targeting structural determinants essential for pathological tau-tau interaction reduces tau oligomerisation and neurofibrillary degeneration in an Alzheimer's disease model. Alzheimers Res. Ther. 6, 44 https://doi.org/10.1186/alzrt278

Kontsekova E, Zilka N, Kovacech B, Skrabana R, Novak M (2014b): Identification of structural determinants on tau protein essential for its pathological function: novel therapeutic target for tau immunotherapy in Alzheimer's disease. Alzheimers Res. Ther. 6, 45 https://doi.org/10.1186/alzrt277

Kovac A, Zilka N, Kazmerova Z, Cente M, Zilkova M, Novak M (2011): Misfolded truncated protein tau induces innate immune response via MAPK pathway. J. Immunol. 187, 2732-2739 https://doi.org/10.4049/jimmunol.1100216

Krasemann S, Madore C, Cialic R, Baufeld C, Calcagno N, El Fatimy R, Beckers L, O'Loughlin E, Xu Y, Fanek Z, et al. (2017): The TREM2-APOE pathway drives the transcriptional phenotype of dysfunctional microglia in neurodegenerative diseases. Immunity 47, 566-581 https://doi.org/10.1016/j.immuni.2017.08.008

Lee SH, Le Pichon CE, Adolfsson O, Gafner V, Pihlgren M, Lin H, Solanoy H, Brendza R, Ngu H, Foreman O, et al. (2016): Antibody-mediated targeting of tau in vivo does not require effector function and microglial engagement. Cell. Rep. 16, 1690-1700 https://doi.org/10.1016/j.celrep.2016.06.099

Leng F, Edison P (2021): Neuroinflammation and microglial activation in Alzheimer disease: where do we go from here? Nat. Rev. Neurol. 17, 157-172 https://doi.org/10.1038/s41582-020-00435-y

Lenz KM, Nelson LH (2018): Microglia and beyond: innate immune cells as regulators of brain development and behavioral function. Front. Immunol. 9, 698 
https://doi.org/10.3389/fimmu.2018.00698

Leyns CEG, Ulrich JD, Finn MB, Stewart FR, Koscal LJ, Remolina Serrano J, Robinson GO, Anderson E, Colonna M, Holtzman DM (2017): TREM2 deficiency attenuates neuroinflammation and protects against neurodegeneration in a mouse model of tauopathy. Proc. Natl. Acad. Sci. USA 114, 11524-11529 https://doi.org/10.1073/pnas.1710311114

Li Y, Liu L, Barger SW, Griffin WS (2003): Interleukin-1 mediates pathological effects of microglia on tau phosphorylation and on synaptophysin synthesis in cortical neurons through a p38MAPK pathway. J. Neurosci. 23, 1605-1611 https://doi.org/10.1523/JNEUROSCI.23-05-01605.2003

Liu F, Liang Z, Shi J, Yin D, El-Akkad E, Grundke-Iqbal I, Iqbal K, Gong CX (2006): PKA modulates GSK-3beta- and cdk5catalyzed phosphorylation of tau in site- and kinase-specific manners. FEBS Lett. 580, 6269-6274 https://doi.org/10.1016/j.febslet.2006.10.033

Lopez Salon M, Morelli L, Castano EM, Soto EF, Pasquini JM (2000): Defective ubiquitination of cerebral proteins in Alzheimer's disease. J. Neurosci. Res. 62, 302-310

https://doi.org/10.1002/1097-4547(20001015)62:2<302::AID-JNR15>3.0.CO;2-L

Luo W, Liu W, Hu X, Hanna M, Caravaca A, Paul SM (2015): Microglial internalization and degradation of pathological tau is enhanced by an anti-tau monoclonal antibody. Sci. Rep. 5, 11161 https://doi.org/10.1038/srep11161

Majerova P, Zilkova M, Kazmerova Z, Kovac A, Paholikova K, Kovacech B, Zilka N, Novak M (2014): Microglia display modest phagocytic capacity for extracellular tau oligomers. J. Neuroinflammation 11, 161

https://doi.org/10.1186/s12974-014-0161-z

Mantovani A, Sozzani S, Locati M, Allavena P, Sica A (2002): Macrophage polarization: tumor-associated macrophages as a paradigm for polarized M2 mononuclear phagocytes. Trends Immunol. 23, 549-555 https://doi.org/10.1016/S1471-4906(02)02302-5

Martini-Stoica H, Cole AL, Swartzlander DB, Chen F, Wan YW, Bajaj L, Bader DA, Lee VMY, Trojanowski JQ, Liu Z, et al. (2018): TFEB enhances astroglial uptake of extracellular tau species and reduces tau spreading. J. Exp. Med. 215, 2355-2377 https://doi.org/10.1084/jem.20172158

Mastroeni D, Khdour OM, Delvaux E, Nolz J, Olsen G, Berchtold N, Cotman C, Hecht SM, Coleman PD (2017): Nuclear but not mitochondrial-encoded oxidative phosphorylation genes are altered in aging, mild cognitive impairment, and Alzheimer's disease. Alzheimers Dement. 13, 510-519 https://doi.org/10.1016/j.jalz.2016.09.003

Matt SM, Lawson MA, Johnson RW (2016): Aging and peripheral lipopolysaccharide can modulate epigenetic regulators and decrease IL-1beta promoter DNA methylation in microglia. Neurobiol. Aging 47, 1-9 https://doi.org/10.1016/j.neurobiolaging.2016.07.006

McEwan WA, Falcon B, Vaysburd M, Clift D, Oblak AL, Ghetti B, Goedert M, James LC (2017): Cytosolic Fc receptor TRIM21 inhibits seeded tau aggregation. Proc. Natl. Acad. Sci. USA 114, 574-579 https://doi.org/10.1073/pnas.1607215114
Melov S, Adlard PA, Morten K, Johnson F, Golden TR, Hinerfeld D, Schilling B, Mavros C, Masters CL, Volitakis I, et al. (2007): Mitochondrial oxidative stress causes hyperphosphorylation of tau. PLoS One 2, e536 https://doi.org/10.1371/journal.pone.0000536

Miller KR, Streit WJ (2007): The effects of aging, injury and disease on microglial function: a case for cellular senescence. Neuron Glia Biol. 3, 245-253 https://doi.org/10.1017/S1740925X08000136

Mittelbronn M, Dietz K, Schluesener HJ, Meyermann R (2001): Local distribution of microglia in the normal adult human central nervous system differs by up to one order of magnitude. Acta Neuropathol. 101, 249-255 https://doi.org/10.1007/s004010000284

Montagne A, Barnes SR, Sweeney MD, Halliday MR, Sagare AP, Zhao Z, Toga AW, Jacobs RE, Liu CY, Amezcua L, et al. (2015): Blood-brain barrier breakdown in the aging human hippocampus. Neuron 85, 296-302 https://doi.org/10.1016/j.neuron.2014.12.032

Morales I, Jimenez JM, Mancilla M, Maccioni RB (2013): Tau oligomers and fibrils induce activation of microglial cells. J Alzheimers Dis. 37, 849-856 https://doi.org/10.3233/JAD-131843

Murgoci AN, Duhamel M, Raffo-Romero A, Mallah K, Aboulouard S, Lefebvre C, Kobeissy F, Fournier I, Zilkova M, Maderova D, et al. (2020): Location of neonatal microglia drives small extracellular vesicles content and biological functions in vitro. J. Extracell. Vesicles 9, 1727637 https://doi.org/10.1080/20013078.2020.1727637

Neher JJ, Cunningham C (2019): Priming microglia for innate immune memory in the brain. Trends Immunol. 40, 358-374 https://doi.org/10.1016/j.it.2019.02.001

Norden DM, Trojanowski PJ, Villanueva E, Navarro E, Godbout JP (2016): Sequential activation of microglia and astrocyte cytokine expression precedes increased Iba-1 or GFAP immunoreactivity following systemic immune challenge. Glia 64, 300-316 https://doi.org/10.1002/glia.22930

Novak P, Kontsekova E, Zilka N, Novak M (2018): Ten years of tau-targeted immunotherapy: The path walked and the roads ahead. Front. Neurosci. 12, 798 https://doi.org/10.3389/fnins.2018.00798

Novak P, Kovacech B, Katina S, Schmidt R, Scheltens P, Kontsekova E, Ropele S, Fialova L, Kramberger M, Paulenka-Ivanovova N, et al. (2021): ADAMANT: a placebo-controlled randomized phase 2 study of AADvac1, an active immunotherapy against pathological tau in Alzheimer's disease. Nature Aging 1, 521534 https://doi.org/10.1038/s43587-021-00070-2

Novak P, Schmidt R, Kontsekova E, Zilka N, Kovacech B, Skrabana R, Vince-Kazmerova Z, Katina S, Fialova L, Prcina M, et al. (2017): Safety and immunogenicity of the tau vaccine AADvac1 in patients with Alzheimer's disease: a randomised, double-blind, placebo-controlled, phase 1 trial. Lancet Neurol. 16, 123-134 https://doi.org/10.1016/S1474-4422(16)30331-3

Olah M, Menon V, Habib N, Taga MF, Ma Y, Yung CJ, Cimpean M, Khairallah A, Coronas-Samano G, Sankowski R, et al. (2020): 
Single cell RNA sequencing of human microglia uncovers a subset associated with Alzheimer's disease. Nat. Commun. 11, 6129 https://doi.org/10.1038/s41467-020-19737-2

Olah M, Patrick E, Villani AC, Xu J, White CC, Ryan KJ, Piehowski P, Kapasi A, Nejad P, Cimpean M, et al. (2018): A transcriptomic atlas of aged human microglia. Nat. Commun. 9, 539 https://doi.org/10.1038/s41467-018-02926-5

Olson JK, Miller SD (2004): Microglia initiate central nervous system innate and adaptive immune responses through multiple TLRs. J. Immunol. 173, 3916-3924 https://doi.org/10.4049/jimmunol.173.6.3916

Overmyer M, Helisalmi S, Soininen H, Laakso M, Riekkinen P, Sr., Alafuzoff I (1999): Reactive microglia in aging and dementia: an immunohistochemical study of postmortem human brain tissue. Acta Neuropathol. 97, 383-392 https://doi.org/10.1007/s004010051002

Phiel CJ, Wilson CA, Lee VM, Klein PS (2003): GSK-3alpha regulates production of Alzheimer's disease amyloid-beta peptides. Nature 423, 435-439 https://doi.org/10.1038/nature01640

Polydoro M, Acker CM, Duff K, Castillo PE, Davies P (2009): Age-dependent impairment of cognitive and synaptic function in the htau mouse model of tau pathology. J. Neurosci. 29, 10741-10749 https://doi.org/10.1523/JNEUROSCI.1065-09.2009

Pozzo ED, Tremolanti C, Costa B, Giacomelli C, Milenkovic VM, Bader S, Wetzel CH, Rupprecht R, Taliani S, Settimo FD, Martini C (2019): Microglial pro-inflammatory and anti-inflammatory phenotypes are modulated by translocator protein activation. Int. J. Mol. Sci. 20, 4467 https://doi.org/10.3390/ijms20184467

Prince M, Wimo A, Guerchet M, Ali GC, Wu Y, Prina M (2015): World Alzheimer Report 2015. The Global Impact of Dementia: An Analysis of Prevalence, Incidence, Cost and Trends. Alzheimer's Disease International, London

Quintanilla RA, Orellana DI, Gonzalez-Billault C, Maccioni RB (2004): Interleukin-6 induces Alzheimer-type phosphorylation of tau protein by deregulating the $\mathrm{cdk} 5 / \mathrm{p} 35$ pathway. Exp. Cell Res. 295, 245-257 https://doi.org/10.1016/j.yexcr.2004.01.002

Quintanilla RA, von Bernhardi R, Godoy JA, Inestrosa NC, Johnson GV (2014): Phosphorylated tau potentiates Abeta-induced mitochondrial damage in mature neurons. Neurobiol. Dis. 71, 260-269 https://doi.org/10.1016/j.nbd.2014.08.016

Ramesh Babu J, Lamar Seibenhener M, Peng J, Strom A. L, Kemppainen R, Cox N, Zhu H, Wooten MC, Diaz-Meco MT, Moscat J, Wooten MW (2008): Genetic inactivation of p62 leads to accumulation of hyperphosphorylated tau and neurodegeneration. J. Neurochem. 106, 107-120 https://doi.org/10.1111/j.1471-4159.2008.05340.x

Ren C, Li D, Zhou Q, Hu X (2020): Mitochondria-targeted TPPMoS2 with dual enzyme activity provides efficient neuroprotection through M1/M2 microglial polarization in an Alzheimer's disease model. Biomaterials 232, 119752 https://doi.org/10.1016/j.biomaterials.2019.119752

Reu P, Khosravi A, Bernard S, Mold JE, Salehpour M, Alkass K, Perl S, Tisdale J, Possnert G, Druid H, Frisen J (2017): The lifespan and turnover of microglia in the human brain. Cell. Rep. 20, 779-784 https://doi.org/10.1016/j.celrep.2017.07.004

Rhein V, Song X, Wiesner A, Ittner LM, Baysang G, Meier F, Ozmen L, Bluethmann H, Drose S, Brandt U, et al. (2009): Amyloidbeta and tau synergistically impair the oxidative phosphorylation system in triple transgenic Alzheimer's disease mice. Proc. Natl. Acad. Sci. USA 106, 20057-20062 https://doi.org/10.1073/pnas.0905529106

Rivera-Escalera F, Pinney JJ, Owlett L, Ahmed H, Thakar J, Olschowka JA, Elliott MR, O`Banion MK (2019): IL-1beta-driven amyloid plaque clearance is associated with an expansion of transcriptionally reprogrammed microglia. J. Neuroinflammation 16, 261 https://doi.org/10.1186/s12974-019-1645-7

Rosenqvist N, Asuni AA, Andersson CR, Christensen S, Daechsel JA, Egebjerg J, Falsig J, Helboe L, Jul P, Kartberg F, et al. (2018): Highly specific and selective anti-pS396-tau antibody C10.2 targets seeding-competent tau. Alzheimers Dement. (NY) 4, 521-534 https://doi.org/10.1016/j.trci.2018.09.005

Saez TE, Pehar M, Vargas M, Barbeito L, Maccioni RB (2004): Astrocytic nitric oxide triggers tau hyperphosphorylation in hippocampal neurons. In Vivo 18, 275-280

Sahara N, Murayama M, Mizoroki T, Urushitani M, Imai Y, Takahashi R, Murata S, Tanaka K, Takashima A (2005): In vivo evidence of CHIP up-regulation attenuating tau aggregation. J. Neurochem. 94, 1254-1263 https://doi.org/10.1111/j.1471-4159.2005.03272.x

Schulz KL, Eckert A, Rhein V, Mai S, Haase W, Reichert AS, Jendrach M, Muller WE, Leuner K (2012): A new link to mitochondrial impairment in tauopathies. Mol. Neurobiol. 46, 205-216 https://doi.org/10.1007/s12035-012-8308-3

Shahpasand K, Uemura I, Saito T, Asano T, Hata K, Shibata K, Toyoshima Y, Hasegawa M, Hisanaga S (2012): Regulation of mitochondrial transport and inter-microtubule spacing by tau phosphorylation at the sites hyperphosphorylated in Alzheimer's disease. J. Neurosci. 32, 2430-2441

https://doi.org/10.1523/JNEUROSCI.5927-11.2012

Sheffield LG, Marquis JG, Berman NE (2000): Regional distribution of cortical microglia parallels that of neurofibrillary tangles in Alzheimer's disease. Neurosci Lett. 285, 165-168 https://doi.org/10.1016/S0304-3940(00)01037-5

Sheng J, Ruedl C, Karjalainen K (2015): Most tissue-resident macrophages except microglia are derived from fetal hematopoietic stem cells. Immunity 43, 382-393 https://doi.org/10.1016/j.immuni.2015.07.016

Sheng JG, Jones RA, Zhou XQ, McGinness JM, Van Eldik LJ, Mrak RE, Griffin WS (2001): Interleukin-1 promotion of MAPK-p38 overexpression in experimental animals and in Alzheimer's disease: potential significance for tau protein phosphorylation. Neurochem. Int. 39, 341-348 https://doi.org/10.1016/S0197-0186(01)00041-9

Small SA, Duff K (2008): Linking Abeta and tau in late-onset Alzheimer's disease: a dual pathway hypothesis. Neuron 60, 534-542

https://doi.org/10.1016/j.neuron.2008.11.007

Swanson MEV, Scotter EL, Smyth LCD, Murray HC, Ryan B, Turner C, Faull RLM, Dragunow M, Curtis MA (2020): Identification 
of a dysfunctional microglial population in human Alzheimer's disease cortex using novel single-cell histology image analysis. Acta Neuropathol. Commun. 8, 170 https://doi.org/10.1186/s40478-020-01047-9

Theunis C, Crespo-Biel N, Gafner V, Pihlgren M, Lopez-Deber MP, Reis P, Hickman DT, Adolfsson O, Chuard N, Ndao DM, et al. (2013): Efficacy and safety of a liposome-based vaccine against protein Tau, assessed in tau.P301L mice that model tauopathy. PLoS One 8, e72301 https://doi.org/10.1371/journal.pone.0072301

Ulland TK, Colonna M (2018): TREM2 - a key player in microglial biology and Alzheimer disease. Nat. Rev. Neurol. 14, 667-675 https://doi.org/10.1038/s41582-018-0072-1

Varvel NH, Neher JJ, Bosch A, Wang W, Ransohoff RM, Miller RJ, Dingledine R (2016): Infiltrating monocytes promote brain inflammation and exacerbate neuronal damage after status epilepticus. Proc. Natl. Acad. Sci. USA 113, E5665-5674 https://doi.org/10.1073/pnas.1604263113

Versijpt JJ, Dumont F, Van Laere KJ, Decoo D, Santens P, Audenaert K, Achten E, Slegers G, Dierckx RA, Korf J (2003): Assessment of neuroinflammation and microglial activation in Alzheimer's disease with radiolabelled PK11195 and single photon emission computed tomography. A pilot study. Eur. Neurol. 50, 39-47 https://doi.org/10.1159/000070857

Wang Y, Cella M, Mallinson K, Ulrich JD, Young KL, Robinette ML, Gilfillan S, Krishnan GM, Sudhakar S, Zinselmeyer BH, et al. (2015): TREM2 lipid sensing sustains the microglial response in an Alzheimer's disease model. Cell 160, 1061-1071 https://doi.org/10.1016/j.cell.2015.01.049

Weisova P, Cehlar O, Skrabana R, Zilkova M, Filipcik P, Kovacech B, Prcina M, Wojciakova L, Fialova L, Smolek T, et al. (2019): Therapeutic antibody targeting microtubule-binding domain prevents neuronal internalization of extracellular tau via masking neuron surface proteoglycans. Acta Neuropathol. Commun. 7, 129 https://doi.org/10.1186/s40478-019-0770-y

Wes PD, Sayed FA, Bard F, Gan L (2016): Targeting microglia for the treatment of Alzheimer's disease. Glia 64, 1710-1732 https://doi.org/10.1002/glia.22988

Wong ES, Tan JM, Soong WE, Hussein K, Nukina N, Dawson VL, Dawson TM, Cuervo AM, Lim KL (2008): Autophagy-mediated clearance of aggresomes is not a universal phenomenon. Hum. Mol. Genet. 17, 2570-2582 https://doi.org/10.1093/hmg/ddn157

Xie N, Wu C, Wang C, Cheng X, Zhang L, Zhang H, Lian Y (2017): Inhibition of the mitochondrial calcium uniporter inhibits Abeta-induced apoptosis by reducing reactive oxygen species- mediated endoplasmic reticulum stress in cultured microglia. Brain Res. 1676, 100-106 https://doi.org/10.1016/j.brainres.2017.08.035

Xu Y, Zhang S, Zheng H (2019): The cargo receptor SQSTM1 ameliorates neurofibrillary tangle pathology and spreading through selective targeting of pathological MAPT (microtubule associated protein tau). Autophagy 15, 583-598 https://doi.org/10.1080/15548627.2018.1532258

Yanamandra K, Jiang H, Mahan TE, Maloney SE, Wozniak DF, Diamond MI, Holtzman DM (2015): Anti-tau antibody reduces insoluble tau and decreases brain atrophy. Ann. Clin. Transl. Neurol. 2, 278-288 https://doi.org/10.1002/acn3.176

Yanamandra K, Kfoury N, Jiang H, Mahan TE, Ma S, Maloney SE, Wozniak DF, Diamond MI, Holtzman DM (2013): Anti-tau antibodies that block tau aggregate seeding in vitro markedly decrease pathology and improve cognition in vivo. Neuron 80, $402-414$ https://doi.org/10.1016/j.neuron.2013.07.046

Yokokura M, Mori N, Yagi S, Yoshikawa E, Kikuchi M, Yoshihara Y, Wakuda T, Sugihara G, Takebayashi K, Suda S, et al. (2011): In vivo changes in microglial activation and amyloid deposits in brain regions with hypometabolism in Alzheimer's disease. Eur. J. Nucl. Med. Mol. Imaging 38, 343-351 https://doi.org/10.1007/s00259-010-1612-0

Yoshiyama Y, Higuchi M, Zhang B, Huang SM, Iwata N, Saido TC, Maeda J, Suhara T, Trojanowski JQ, Lee VM (2007): Synapse loss and microglial activation precede tangles in a P301S tauopathy mouse model. Neuron 53, 337-351 https://doi.org/10.1016/j.neuron.2007.01.010

Zelcer N, Khanlou N, Clare R, Jiang Q, Reed-Geaghan EG, Landreth GE, Vinters HV, Tontonoz P (2007): Attenuation of neuroinflammation and Alzheimer's disease pathology by liver x receptors. Proc. Natl. Acad. Sci. USA 104, 10601-10606 https://doi.org/10.1073/pnas.0701096104

Zhang H, Su YJ, Zhou WW, Wang SW, Xu PX, Yu XL, Liu RT (2014): Activated scavenger receptor A promotes glial internalization of abeta. PLoS One 9, e94197 https://doi.org/10.1371/journal.pone.0094197

Zilkova M, Nolle A, Kovacech B, Kontsekova E, Weisova P, Filipcik P, Skrabana R, Prcina M, Hromadka T, Cehlar O, et al. (2020): Humanized tau antibodies promote tau uptake by human microglia without any increase of inflammation. Acta Neuropathol. Commun. 8, 74 https://doi.org/10.1186/s40478-020-00948-Z

Received: April 30, 2021

Final version accepted: August 13, 2021 